Open Access

\title{
Recent evidence of the development of micro, small and medium enterprises in Indonesia
}

\author{
Tulus Tambunan
}

\author{
Correspondence: \\ ttambunan56@yahoo.com \\ Center for Industry, SME \& Business \\ Competition Studies, University of \\ Trisakti, Jakarta, Indonesia
}

\begin{abstract}
This paper examines the development of micro, small and medium enterprises (MSMEs) in Indonesia. It has three research issues, namely the role of MSMEs, their constraints, and the importance of MSMEs for the creation of business opportunities for women. More specifically, the study aims to answer the following research questions. First, how important are MSMEs in Indonesia? Second, what are their main constraints? Third, how important are they, especially micro and small enterprises (MSEs), for the creation of business opportunities for women? Fourth, is the growth of MSEs a sign of increased entrepreneurial spirit or a reflection of poverty? This study adopted descriptive analysis using secondary data. It shows that MSMEs in Indonesia are dominated by MSEs, and accounted for almost 100\% of all existing firms but only contributed between 58 to $61 \%$ of gross domestic product (GDP). About $42.84 \%$ of MSEs are owned by women, although the ratio of female to male entrepreneurs in MSEs varies by province. Poverty seems to be the main force behind the growth of MSEs. This study ends with some policy recommendations that the government should: (i) conduct trainings that focus on online marketing, entrepreneurship, management, and improving the quality of product and business efficiency; (ii) provide alternative funding facilities with low interest rates and non-burdensome requirements; and (iii) provide assistance directly in the production site for new entrepreneurs in their first years of running businesses. In addition, all gender discrimination treatments that have been burdensome for women to run own businesses must be eliminated. This study has, however, several limitations, especially with respect to the third and fourth research questions. Secondary data used does not have information about the main/initial motivation of MSME owners to run their own business and their socio-economic profiles.
\end{abstract}

Keywords: Micro, Small and medium enterprises (MSMEs), Micro and small enterprises (MSEs), Microenterprises (MIEs), Large enterprises (LES), Women entrepreneurs, Constraints

\section{Introduction}

It is widely stated in the literature that micro, small and medium enterprises (MSMEs) in developing countries are important socially and economically for a number of reasons, which include: (i) their wide dispersion across rural areas and therefore they are very important for rural economic development; (ii) their ability to absorb a significant large number of workers; (iii) their role as a place for entrepreneurship and business skill development, especially in rural areas; and (iv) as a source of business

(c) The Author(s). 2019 Open Access This article is distributed under the terms of the Creative Commons Attribution 4.0 International License (http://creativecommons.org/licenses/by/4.0/), which permits unrestricted use, distribution, and reproduction in any medium, provided you give appropriate credit to the original author(s) and the source, provide a link to the Creative Commons license, and indicate if changes were made. 
opportunities for women. However, their development is hampered by a number of constraints, and most significant being the lack of access to bank loans and difficulties in marketing (Orlando \& Pollack, 2000; Midgley, 2008; Tambunan, 2009a,b; Yuhua, 2013; Das \& Mohiuddin, 2015; Oyelana \& Adu, 2015; Shah \& Saurabh, 2015; Santos \& Moustafa;2016;Thapa, 2016; Raghuvanshi, Agrawal \& Ghosh, 2017).

Recognizing the importance of MSMEs and constraints they face as discussed above, the Indonesian government has taken many measures to support them. The measures include the issuance of a number of regulations in the past two decades especially to facilitate MSMEs in the marketing and procurement of raw materials, and in funding by launching a public non-collateral credit guarantee scheme, well-known as Kredit Usaha Rakyat in 2007 (Tambunan, 2018).

Based on this background, the main objective of this study is to examine the development of MSMEs in Indonesia with the emphasis on the following three issues: (1) the role of MSMEs; (2) their main constraints; and (3) the importance of these enterprises, especially micro and small enterprises (MSEs), for the creation of business opportunities for women. More specifically, this study aims to answer the following four research questions. First, how important are MSMEs in Indonesia? Second, what are their main constraints? Third, how important are these enterprises for the creation of business opportunities for women?. Fourth, is the growth of particularly MSEs a sign of increased entrepreneurial spirit or a reflection of poverty?

Methodologically, this study adopted descriptive analysis, using secondary data on MSMEs in Indonesia. The data were obtained from two sources, namely: (i) national data on development of MSMEs for the period of 1997-2017 from the Ministry of Cooperative and SME (online data); and (ii) data on MSEs in the manufacturing industry for 2015 (National Survey on Micro and Small Industry (NSMSI) 2015), data on MSEs in non-agricultural sectors for 2016 (National Economic Census (NEC) 2016), and data on real income and poverty per province for 2016 (Indonesian Statistics 2016) from the National Agency of Statistics (BPS).

This study is important because it is the first study on MSMEs, particularly MSEs, in Indonesia based on the latest data from the 2016 NEC and the 2015 MSMSI, and this Indonesian case especially the involvement of women in these enterprises may have a significant contribution to the existing literature on MSMEs and women empowerment in developing countries.

\section{Definitions of MSMEs}

In Indonesia, the definition of MSMEs is set in Law Number 20, 2008. In Article 1 in Chapter I (general provisions) of the Law, it is stated that microenterprise (MIE) is a productive business independently owned by an individual person or a business entity fulfilling the criteria of MIE as stipulated in the Law. Small enterprise (SE) is a stand-alone productive economic enterprise undertaken by an individual person or a business entity which is not a subsidiary or not a branch of a company owned, controlled, or becomes part, either directly or indirectly, of a medium enterprise (ME) or a large enterprise (LE) that meets the SE criteria as stated in the Act. While ME is a stand-alone productive economic enterprise undertaken by an individual person or a business entity that is not a subsidiary or not a branch of a company owned, controlled, 
or becomes part, directly or indirectly, of a MIE, a SE or a LE that meets the criteria of ME as stipulated in the Act.

In this law, the criteria used to define a MSME as set forth in Article 6 are net asset value excluding land and building of business premises, or annual sales. Under these criteria, MIE is a business unit with an asset value of at most 50 million Indonesian rupiah (Rp), or annual sales of maximum Rp300 million; SE is a business unit with an asset value of more than Rp50 million up to a maximum of Rp500 million, or annual sales of more than Rp.300 million up to a maximum of Rp2.5 billion; and ME is a company with a net worth value of more than Rp500 million up to a maximum of Rp10 billion, or annual sales of over Rp2.5 billion to a maximum of Rp50 billion. Alternatively, BPS adopts the number of workers as the criteria: MIE: 0-4 persons; SE: 5-19 persons; ME: 20-99 persons; and LE: > 99 persons.

\section{Research framework}

A lot of evidence throughout the world, and especially in low-income/poor countries, shows that MSMEs play a crucial role in addressing the impediments of poverty, inequality, and job creation, particularly in rural areas. They are also an important source of employment or business opportunities for low-skilled women and the youth. Even, in many countries, these enterprises are an important growth engine for GDP and export of manufactured goods. However, many (if not all) MSMEs are struggle to sustain or to expand due to many constraints they face, especially lack of access to bank loans, difficulties in marketing, and limited acess to advaced technologies and skilled workers (e.g. Orlando \& Pollack, 2000; Midgley, 2008; Tambunan, 2009a,b, 2010, 2015a, 2018; Yuhua, 2013; Das \& Mohiuddin, 2015; Fiseha \& Oyelana, 2015; Oyelana \& Adu, 2015; Shah \& Saurabh, 2015; Santos \& Moustafa;2016;Thapa, 2016; Raghuvanshi, Agrawal \& Ghosh, 2017).

In the literature on entrepreneurship, it is often stated that the existance or growth of MSMEs in a region reflects the development of the entrepreneurial spirit in that region. Many people choose to run own businesses for various reasons, e.g. flexibility, freedom, independence, achieving dreams, or to earn more money (Orlando \& Pollack, 2000). Entrepreneurship is seen as a process leading to the creation of MSMEs (e.g. Akande \& Ojukuku, 2008; Alarape, 2007; Lucky (2012).

But, since the publication of a paper writen by Dennis Anderson in 1982 that became famous in the literature on MSMEs in developing countries, the question arises: whether the large number of MSMEs, particularly MIEs, in poor countries reflects the high entrepreneurial spirit or more as a sign of poverty (e.g. Tambunan, 1994, 2008; Oyelana \& Adu, 2015; Thapa, 2016; Rambe \& Mosweunyane, 2017).Even, evidence in a number of low-income countries suggests that MIEs function more as the 'last resort' rather than as profitable businesses opportunities for the poor: because they are poor or unemployed, they are forced to conduct any kind of activities that can generate some incomes for them to survive (e.g. Orlando \& Pollack, 2000;Midgley, 2008; Oyelana \& Adu, 2015; Lateh, Hussain \& Halim (2017).

As shown in Table 1, many field studies, e.g. BI \& LPPI (2015), Narayanan (2016), and Tambunan (2017) have found that within the MSMEs, MIEs are obviously different than SEs and MEs in many aspects, which further suggest that MIEs are run mostly by the poor. This may support the view that MIEs are more likely to be positively related to poverty. 
Table 1 Key characteristics of MIEs, SEs, and MEs

\begin{tabular}{|c|c|c|c|c|}
\hline No & Aspect & MIEs & SES & MEs \\
\hline 1 & Formality & $\begin{array}{l}\text { Degree of informality is high } \\
\text { (most are operated in the } \\
\text { informal sector). }\end{array}$ & $\begin{array}{l}\text { Degree of informality is } \\
\text { lower (many are } \\
\text { operated in the formal } \\
\text { sector) }\end{array}$ & $\begin{array}{l}\text { All are operated in the } \\
\text { formal sector. }\end{array}$ \\
\hline 2 & $\begin{array}{l}\text { Organisation } \\
\& \text { management }\end{array}$ & Primitive/traditional & $\begin{array}{l}\text { Many are non-primitive } \\
\text { units with modern } \\
\text { management systems }\end{array}$ & $\begin{array}{l}\text { All have formal } \\
\text { organisational structure } \\
\text { with modern } \\
\text { management systems }\end{array}$ \\
\hline 3 & Workers used & $\begin{array}{l}\text { Most are family businesses; } \\
\text { they use unpaid family members } \\
\text { as workers/helpers }\end{array}$ & $\begin{array}{l}\text { Many use wage-paid } \\
\text { employees }\end{array}$ & $\begin{array}{l}\text { All use wage-paid } \\
\text { employees }\end{array}$ \\
\hline 4 & Production process & Traditional/manually & $\begin{array}{l}\text { Many are highly } \\
\text { mechanised }\end{array}$ & $\begin{array}{l}\text { Degree of automation is } \\
\text { much higher }\end{array}$ \\
\hline 5 & Market orientation & $\begin{array}{l}\text { Most are very local oriented; } \\
\text { served local low income } \\
\text { households }\end{array}$ & $\begin{array}{l}\text { Local, national and/or } \\
\text { export }\end{array}$ & National and/or export \\
\hline 6 & $\begin{array}{l}\text { Economic \& social } \\
\text { profile of the owner }\end{array}$ & Non-/low educated and poor & $\begin{array}{l}\text { Many are well } \\
\text { educated and from } \\
\text { non-poor families }\end{array}$ & $\begin{array}{l}\text { Most are well-educated } \\
\text { and from medium to } \\
\text { high-income families. }\end{array}$ \\
\hline 7 & Technoloy used & $\begin{array}{l}\text { In general, they use 'out of date' } \\
\text { machines or manually and do not } \\
\text { utilise information technology (IT) }\end{array}$ & $\begin{array}{l}\text { Many use machines } \\
\text { and utilise IT. }\end{array}$ & $\begin{array}{l}\text { Degree of modern } \\
\text { technology used is } \\
\text { much higher and all } \\
\text { utilise IT. }\end{array}$ \\
\hline 8 & $\begin{array}{l}\text { Owner/ } \\
\text { entrepreneur by } \\
\text { gender }\end{array}$ & $\begin{array}{l}\text { Many MIEs are owned/managed } \\
\text { by women }\end{array}$ & $\begin{array}{l}\text { Less women are } \\
\text { involved as owners/ } \\
\text { entrepreneurs }\end{array}$ & $\begin{array}{l}\text { Very few women as } \\
\text { owners/entrepreneurs }\end{array}$ \\
\hline 9 & $\begin{array}{l}\text { Reason/motivation } \\
\text { to run own } \\
\text { business }\end{array}$ & In general to survive & Mostly for profit & All for profit \\
\hline 10 & $\begin{array}{l}\text { Spirit of entrepre- } \\
\text { neurship }\end{array}$ & In general low & Mostly high & All high \\
\hline
\end{tabular}

Sources: BI \& LPPI (2015), Narayanan (2016),Tambunan (2017)

\section{Results and discussion}

Development of MSMEs

One characteristic of the Indonesian economy is that domestic economic activities are dominated by MSMEs; although the ratio of MSMEs to LEs varies across different economic sectors. For example in the mining sector, particularly in oil, gas and coal, where there are mainly LEs, including foreign companies, the ratio is lower than in other sectors such as trade, manufacturing industry and agriculture. Of the total existing MSMEs, most of them are from the MIE category (99\%). As shown in Fig. 1, according to the official time series data issued by the Ministry of Cooperative and SME for the period of 1997-2017, the total number of MSMEs in Indonesia increased every year from 39.765 million units (or about $99.8 \%$ of the total business units in Indonesia) in 1997 to more than 59 million units by 2017 (or 99.9\%), except in 1998, when the Asian financial crisis hit Indonesia, the number of MSMEs dropped by more than $7 \%$. In 1999 as the national economy started to recover, MLSEs also recovered with a positive growth rate of almost 3\% (Fig. 2). Most MSMEs that were out of business during the crisis were heavily dependent on imported raw materials which then very expensive in rupiah because of the depreciation of the national currency against the US dollar by more than $500 \%$ in mid-1998, while domestic demand for their products also declined 


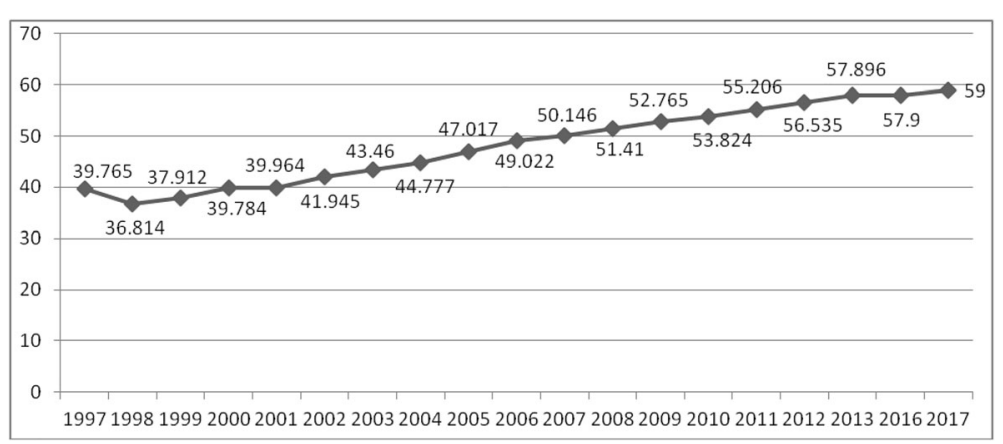

Fig. 1 Total number of MSMEs in all sectors, 1997-2017 (million units). Source: the Ministry of Cooperative and SME (http://www.depkop.go.id/berita-informasi/data-informasi/data-umkm/)

due to very high domestic inflation. Many MSMEs had to stop operating at that time because it was hard to get bank loans as the national bank also hit by the crisis. Also many MSMEs which had production linkages with LEs through subcontracting arrangements were forced to close because there were no more orders from the LEs.

Concerning their contribution to the formation of GDP, MSMEs always play a smaller role compared to their contribution to employment generation. While their share in total employment was around 99\%, they accounted for only approximately 61.41\% of GDP in 2017 (Fig. 3). The same thing was also found by Yuhua (2013) from her study in the Asia-Pacific region, which shows that in all countries in the region, more than $90 \%$ of total employment was generated by MSMEs but their contribution to GDP was much below 90\%; although the ratio varies by economy.

The lower contribution of MSMEs to the formation of GDP compared to their role in job creation is due to many factors, including their limited access to advanced technologies, capital and human resource that resulted in their much lower productivity than that in LEs. In other words, their greater share of GDP than that of LEs is simply because the number of companies from the MSME category is far more than the number of LEs.

In terms of exports, the official data show that during the period of 2007-2013 exports of MSMEs increased from Rp140.4 trillion in 2007 to Rp 182 trillion in 2013, although there were decreases in certain years throughout the period with the largest decline occurred in 2012 by $15.58 \%$ (Table 2). The world economy that was sluggish at

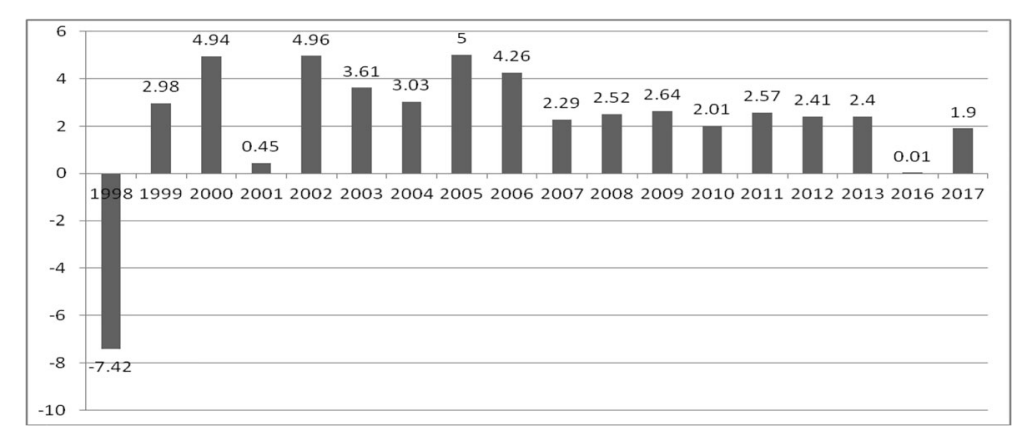

Fig. 2 Growth rate of total number of MSMEs in all sectors, 1998-2017 (\%). Source: the Ministry of Cooperative and SME (http://www.depkop.go.id/berita-informasi/data-informasi/data-umkm/) 


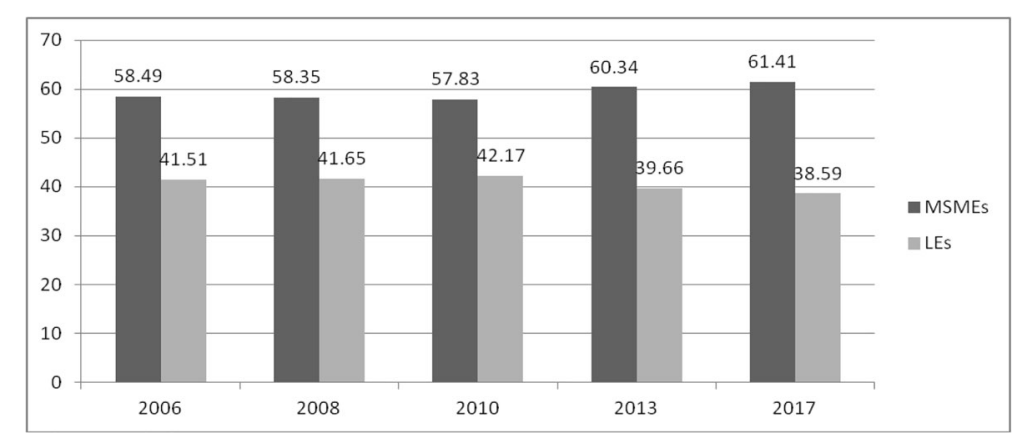

Fig. 3 GDP shares of MSMEs and LEs, 2006-2017 (\%). Source: the Ministry of Cooperative and SME (http://www.depkop.go.id/berita-informasi/data-informasi/data-umkm/

that time could be one of the causes that resulted in lower demands for Indonesian exports from Indonesia's trading partners. Goods which have been the main export products of Indonesian MSMEs are wood products (including furniture), footwear, textile products (including garments), food, beverages, tobacco, fertilizers, chemical products, and goods made from rubber.

MSMEs are still relatively weak compared to their larger counterparts in export. Their share in Indonesian total exports has never reached beyond 19\%. Within the MSME sector, total exports of MSEs are much less compared to those of MEs. In 2013, for instance, their share was only $4.14 \%$, compared to MEs with $11.54 \%$. The smaller export contribution of MSMEs (especially MSEs) compared to that of LEs is due to a number of obstacles faced by them in doing export, including the difficulty in getting export permits (although in recent years the government has been trying to facilitate and simplify the processing of export licenses by, among others, establishing the Indonesian National Single Window); financing constraints (even though there is a special export financing institution (i.e. the Indonesian Export Financing Agency) in collaboration with the Ministry of Trade and several commercial banks which also have special export financing schemes); lack of skilled manpower with broad knowledge about international trade and English language skill; and lack of export-related information (ADB, 2002; Hapsari, 2014; Tambunan, 2009b, 2017).

Data from the 2016 NEC (BPS, 2017) shows that the majority of MSMEs are found in Java, the most populated island and also the center of economic (i.e. manufacturing industry, trade, construction, agriculture and services) and financial activities in Indonesia. Meanwhile, in Papua and Maluku, the least developed part of the country, the number of businesses in non-agricultural sectors from all sizes is very low, which

Table 2 Development of exports of Indonesian MSMEs, 2007-2013

\begin{tabular}{llllllll}
\hline & 2007 & 2008 & 2009 & 2010 & 2011 & 2012 & 2013 \\
\hline Export Value (Rp billion) - \% of & 140,364 & 178,008 & 162,255 & 175,895 & 187,442 & 166,627 & 182,113 \\
Indonesian total export & 17.7 & 18.1 & 17.0 & 15.8 & 16.4 & 14.1 & 15.7 \\
$\begin{array}{l}\text { Export by key sectors (\%) } \\
\quad\end{array}$ & & & & & & \\
$\quad$ Manufacturing industry & 88.9 & 88.7 & 88.8 & 88.3 & 88.7 & 88.6 & 88.5 \\
$\quad$ Agriculture & 10.3 & 10.4 & 10.3 & 10.7 & 10.4 & 10.5 & 10.5 \\
$\quad$ Other sectors & 0.8 & 0.9 & 0.9 & 1.0 & 0.9 & 0.9 & 1.0 \\
\hline
\end{tabular}

Source: the Ministry of Cooperative and SME (http://www.depkop.go.id/berita-informasi/data-informasi/data-umkm/) 
consists of 451.9 thousand MSEs and 7.5 thousand MLEs, or only about, respectively, $1.8 \%$ and $1.7 \%$ of total non-agricultural business in the country (Table 3 ).

Like in other developing countries, most MSEs in Indonesia are in retail trade, handicrafts, footwear, car and motorcycle reparation and maintenance, food and beverages, tobacco, and textile/garments. This is different from MLEs which are mainly in medium- to high technology-based sectors that require medium to high skilled employees and a lot of capital, such as electronic goods, motor vehicles, chemical products, communication, and construction.

As stated in Table 1, most MSEs, especially MIEs, are family businesses conducted by all family members who do all activities together. The 2016 NEC does not have information on how many MSEs that employed wage-paid employees. The 2015 NSMSI does have which shows that total non-paid workers in MSEs in the manufacturing industry amounted to $63.14 \%$. This percentage, however, varies by group of industry, which suggests that in industries with more complicated production processes that require employees with certain high skills, the family has to hire people from outside. For instance, MSEs with the highest percentage of unpaid workers (at around 78\%) are found in the following industries: textile, wood and cork goods (not including furniture), and woven goods from rattan, bamboo and the like, while those with the lowest level of unpaid workers are found in the automotive industry. The 2015 NSMSI also shows that in the manufacturing industry as a whole, around $63.90 \%$ of MSEs are those with an average payment received per worker per month for 1 (one) million rupiah or more. The remaining 36.10\% are those with wage per worker per month under one million rupiah. The ratio, again, varies by group of industry (BPS, 2015).

Another key characteristic of MSEs as shown in Table 1 is that in general these enterprises are owned or managed by low educated people. The 2015 NSMSI shows that only about $2 \%$ of MSEs in the manufacturing industry are run by individuals with university degree. About $20 \%$ did not even complete their primary school. The main reason behind this is poverty.

Using cross-provincial data from all 34 provinces in Indonesia on real per capita income, the number of poor people as a percentage of total population (poverty level), and the number of MSEs as a percentage of total companies from all size categories, Fig. 4 suggests that there is a negative relationship between the number of MSEs and the level of real income per capita. This can be explained from two different angles, namely from the demand side in the goods and services market and from the supply

Table 3 Distribution of MSEs and MLEs in non-agricultural sectors by island, 2016 (\%)

\begin{tabular}{lll}
\hline Island & MSES & MLES \\
\hline Java & 60.7 & 65.2 \\
Sumatera & 18.6 & 16.6 \\
Wesi & 8.1 & 5.6 \\
Kalimantan & 5.1 & 6.0 \\
Bali \& Nusa Tenggara & 5.7 & 4.9 \\
Papua \& Maluku & 1.8 & 1.7 \\
Total & 100.0 & 100.0 \\
\hline Source: BPS (2017) & &
\end{tabular}

Source: BPS (2017) 


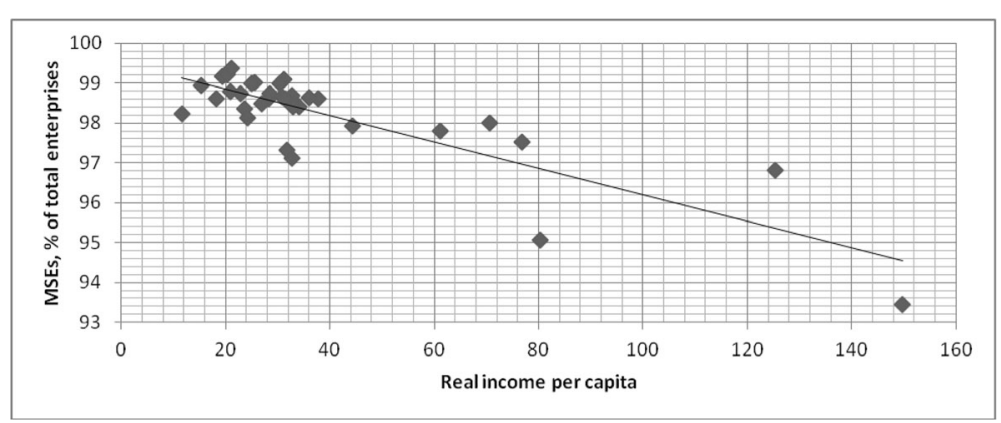

Fig. 4 Scatter MSEs and real income per capita, 2016 (\%). Source: BPS $(2016,2017)$

side in the labor market. From the perspective of the market demand, the higher the average real income, the less demand for goods and services made by MSEs which are mainly of low quality (inferior). As a result, the number of MSEs declines. From the perspective of the labor supply, higher real income usually also signifies greater job opportunities in the formal sector with better incomes, which then discourage people, especially those with better education, to run own businesses in the informal sector or MSEs.

While Fig. 5 suggests that MSEs and poverty are positively related: more poor people/households more MSE activities. This can also be explained from the two perspectives. From the market demand perspective, more poor people generates more market demand for cheap goods and services provided by MSEs. From the labour supply perspective, higher poverty or unemployment rate means more supply of labour to the informal sector, and thus the number of MSEs also increases.

The view as discussed before in the research framework section of this paper that running MSE activities is mainly as a means to survive for the poor tends to be more applicable in the case of MSEs development in Indonesia. In other words, many people in Indonesia are 'pushed' rather than 'pulled' to run MSEs as their only hope to survive.

\section{Women entrepreneurs}

Recently, interest in supporting women's entrepreneurship has increased among policy makers, academics, and practitioners in Indonesia. This interest comes from the recognition that women's entrepreneurship, especially in rural areas, will

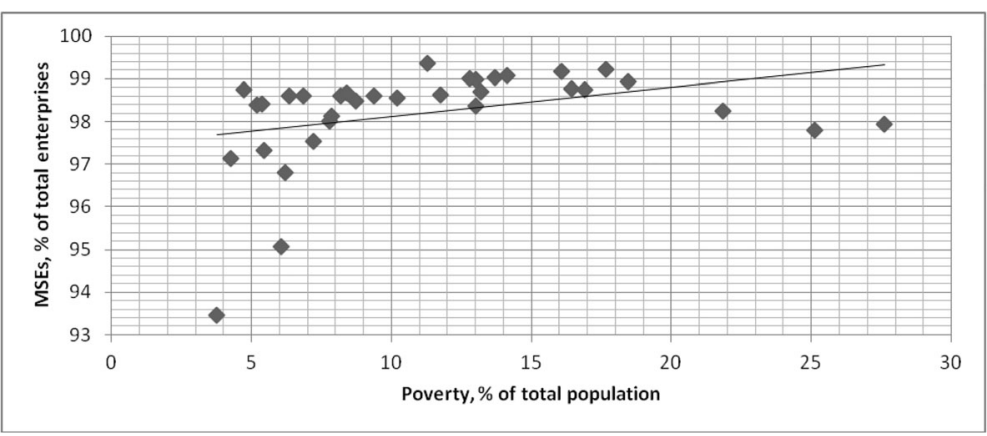

Fig. 5 Scatter MSEs and poverty, 2016 (\%). Source: BPS (2016, 2017) 
contribute to the creation of new rural enterprises that will generate rural economic growth and employment. On the other side, for the women themselves, owning business makes them more independent and provides an opportunity to realize their desire or talent to create something of market value according to their abilities such as bags, clothing, and handicrafts, and perhaps more importantly, to improve family income which means reducing or eliminating poverty (Wijaya, 2008; BPS, 2017). In this respect, MSMEs, especially MSEs, provide a good starting point for the mobilization of women's talent, especially in rural areas, while, at the same time, these enterprises can provide an avenue for the testing and development of women's entrepreneurial ability (Tambunan, 2009c).

Statistics for various years in the period of 1980s-1990s indicate that women entrepreneurs in Indonesia, especially in MSMEs, have increased since the 1980s, when the country achieved rapid economic growth that led to a rapid increase in per capita income. But, their engagement in MSMEs as owners or managers is still much lower compared to men. BPS data on owners of MSMEs by gender in the manufacturing industry in 2006 reveal two interesting facts. First, approximately $29 \%$ of total MSMEs in the sector were operated by women. Second, the proportion of women entrepreneurs tends to decline by size. In MIEs, the percentage of women entrepreneurs is higher than that in SEs, and in the latter it is higher than that in MEs. If total number of enterprises by gender can be used as an indicator of the current state of women's entrepreneurship development in Indonesia, the data may suggest that becoming an entrepreneur, especially in larger and modern businesses in Indonesia, is still predominantly a male occupation (Tambunan, 2009c, 2015).

The 2016 NEC also shows that the percentage of MSEs owned or managed by women is lower than those by men, namely $42.84 \%$ and $57.16 \%$, respectively; although the ratio of female to male entrepreneurs in these enterprises varies by province. Provinces with the ratio higher than 1.0 are Nusa Tenggara Barat (1.12), South Sulawesi (1.02) and West Sumatera (1.01) (Fig. 6). The category of business with the ratio more than 1.0 is in the field of human health and social. Approximately $63.68 \%$ of MSEs in this sector are owned or managed by women. While transportation and warehousing as one sector has the lowest ratio with only $2.22 \%$. This may suggest that there is a difference of tendency in selecting jobs between woman and man. Women tend to avoid heavy or too complicated works or those which involve too much physical.

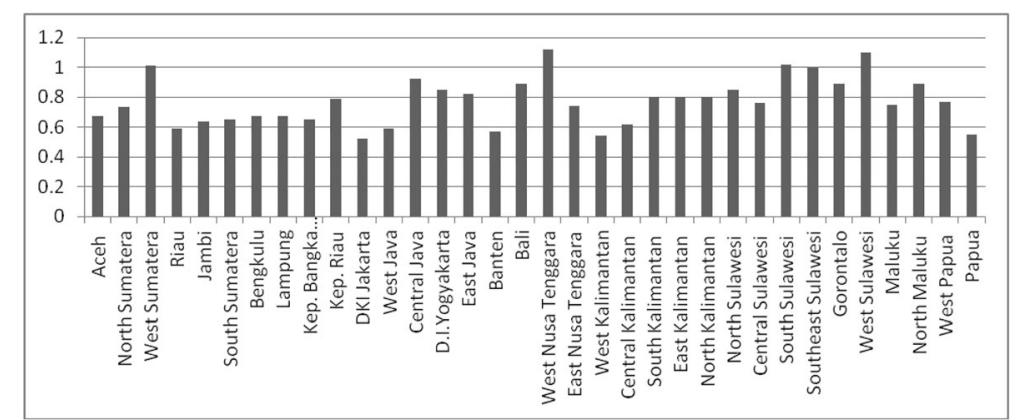

Fig. 6 The ratio of women to men as MSE owner/entrepreneur by province, 2016. Source: BPS (2017) 
Many factors can explain the difference in the ratio of female to male entrepreneurs between the provinces. One of the factors is culture, and in some provinces the culture or tradition of a tribe plays a dominant role. In the Province of West Sumatera, for instance, Minangkabau is the dominant ethnic group. In its culture, the women is the owner of all wealth, home, children, tribe and even her community, and the role of men is only as a protector and keeper of property for their wife and children. The Minangkabau community embraces the matrilineal descendant system, i.e. the family system through the female path. In the household, the wife does not stand idly by but does something that generates income, even though the husband works, for example, weaving at home. Also because migrating outside West Sumatra is a long tradition of Minangkabau men even though they are married, then the wife becomes the main source of family income. Common work done by Minangkabau women, both already and not yet married, is to weave or open a clothing store or a traditional Minangkabau food restaurant.

In the discussion on the increase in the number of women entrepreneurs in developing countries, especially in rural areas, there are two important questions that need to be studied further. First, what are the main causes of the low participation of female as entrepreneurs compared to that of men? Second, is the increase women participation as owners of MSEs a sign of increased entrepreneurial spirit or level of education of women or because of economic pressures or poverty that women faced in their households?

With respect to the first question, it is widely argued in the literature that the relatively low representation of women entrepreneurs in developing countries can be attributed to many factors, which include: (a) lack of education and/or training opportunities that make them disadvantaged in both the economy and society. It is especially true for women living in rural areas where new opportunities to participate in the local economy are limited; (b) social expectations limit opportunities for women's entrepreneurship, especially in rural areas where women are more burdened by traditional roles such as responsibility for housework and childcare; (c) there may be legal, traditional, customary, cultural, or religious constraints on the extent to which women can open their own businesses; and (d) lack of access to formal credit and financial institutions (Tambunan, 2009c, 2015; Santos \& Moustafa, 2016; Raghuvanshi, Agrawal \& Ghosh, 2017).

With respect to the second question, findings from many studies suggest that many women owning micro or small businesses are 'pushed' rather than 'pulled' to earn extra money or to supplement their family incomes (Rusdillah, 1987, Manning, 1998; Oey, 1998; Tambunan, 2009c, 2015b; Das \& Mohiuddin, 2015; Shah \& Saurabh, 2015; Santos \& Moustafa, 2016). For instance, from a survey of MSEs owned by women in several cities in Indonesia, Tambunan (2013) found that not all of them were driven by an entrepreneurial spirit, but because of reasons such as divorce or widowhood, or husbands are unemployed or income of their husbands are not sufficient for family daily needs. This is also one of the reasons that the Indonesian government has been supporting MSEs through various measures so they can play an optimal role as the creator of women's business opportunities, especially in rural areas, which will further reduce poverty.

Unfortunately, as the limitation of this part of the study, the 2016 NEC data used here do not have information about their main/initial motivations to run their own 
businesses rather than to find work elsewhere or stay home and take care of their family/household, which can confirm the findings from these above mentioned studies.

\section{Main constraints}

As also evident in many other developing countries, the development of MSMEs in Indonesia is hampered by several constraints. These constraints may differ from region to region, between different sectors, or between individual enterprises within a sector. However, certain constraints are common to all MSMEs, which include limited access to capital, business information, technology, and skilled workers; difficulties in marketing and getting raw materials; and government policies or regulations which often create an unfriendly business environment. For example, energy policies on fuel and electricity rate or import regulations on raw materials have significant effects on production costs in MSMEs and hence on their price competitiveness and profit.

As shown by the 2015 NSMSI data, the owners of most of the MSEs surveyed (or about 73.96\%) claimed that they had many problems in running their businesses. As can be seen in Fig. 7, three main problems are the difficulty in: (i) getting funds (38.84\%), either for working capital or purchasing new machines; (ii) marketing (25.00\%); and (iii) getting raw material $(22.29 \%)$. The difficulty in getting funds especially from formal sources (e.g. banks and other financial institutions) is caused by various factors, such as business is not feasible, no financial records and no valuable assets as collateral. The difficulty in marketing can be due to many causes, such as expensive place rental rate, difficulty in getting strategic location, no money for promotion, tight competition especially from imported China made goods with very cheap prices, and expensive transportation/distribution costs. Concerning the difficulty in getting raw materials, there are three main causes, namely the required raw materials are not always available in the market, expensive (especially for imported raw material as the rupiah exchange rate against the US dollar tends to weakening since the end of the 1997/ 98 Asian financial crisis), and the place of selling raw materials is often far away which causes high transportation costs.

In addition, most of the enterprises surveyed (95.83\%) had never received supports either from the government or private sector. For those who had ever

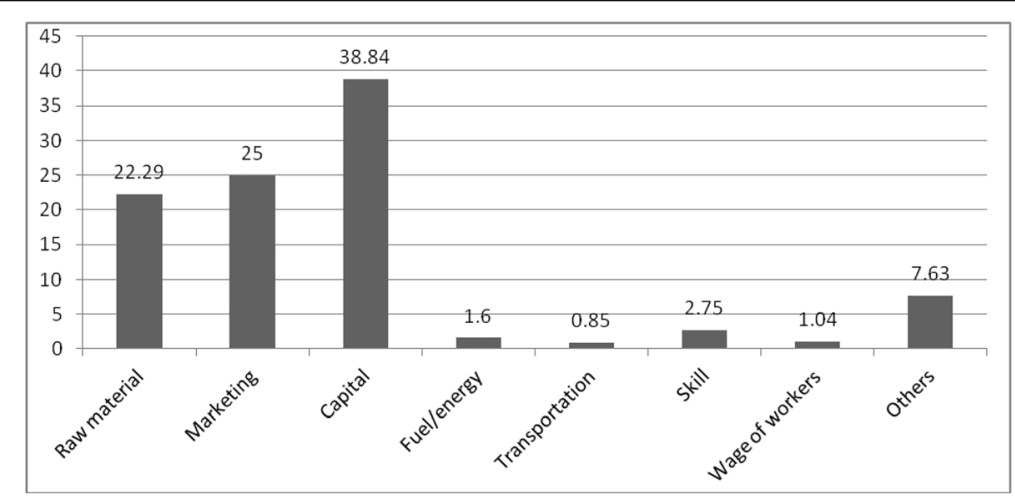

Fig. 7 Percentage of main difficulties experienced by manufacturing MSEs, 2015 (\%). Source: BPS (2015) 
received, the types of service/assistance received most are funding (49.01\%), capital goods $(16.78 \%)$, and raw materials $(12.61 \%)$. Not knowing the existence of various assistance programs or facilities provided by the government or the private sector is the main reason for most of those who had never received (64.61\%). Two other important reasons are: not knowing the procedure $(15.82 \%)$ and not interested (14.81\%).

The above finding is also supported by various studies on MSMEs in many other developing countries, which show that the main constraint is limited access to capital, and followed by difficulties in marketing and lack of technologies and skilled workers (e.g Orlando \& Pollack, 2000; Midgley, 2008; Das \& Mohiuddin, 2015; Oyelana \& Adu, 2015;Santos \& Moustafa;2016;Thapa, 2016).

Unfortunately, which can be considered as the limitation of this part of the study, the 2015 NSMSI does not provide information about constraints by gender and rural-urban areas; only by province and group of manufacturing industry. Even though such information is needed to know whether female owners face more obstacles than male owners do. Also to know if MSEs located in rural areas, especially in rather isolated areas from cities have more limitations to grow than those located in urban areas or cities.

\section{Conclusion}

This study reveals several key facts which add new important information to existing literature not only on MSMEs but also on women entrepreneurship development, particularly in developing countries. First, MSMEs accounted for almost $100 \%$ of all firms, but they contributed not more than $61 \%$ of GDP which means that their productivity is very low due to lack of such as advanced technologies, capital and human resource. These shortages also make them relatively weak in export. Second, less than $50 \%$ of MSEs are owned by women, although the ratio of female to male entrepreneurs in MSE varies by province, depending on various factors, and in some provinces the culture or tradition of a tribe plays a dominant factor. The rate of women entrepreneurs tends to decline by size of business and women tend to avoid heavy or too complex works or those which involve too much physical. Three, poverty tends to play the dominant role behind the growth of MSEs as many people do these activities as a means to survive. Many women owning own micro or small businesses are 'pushed' rather than 'pulled' to run own small businesses to earn extra money or to supplement their family incomes. Fourth, three main difficulties felt by most MSEs in the manufacturing industry are in having access to capital, marketing, and getting raw material.

Finally, the findings from this study are also important for policy makers, not only in Indonesia but also other developing countries, for two main reasons. First, with their huge number, MSMEs are indeed very important not only as a source of employment, but, potentially, as a growth engine for the economy. Second, MSEs are a good starting place for the development of women entrepreneurs. This means that these enterprises do have an important role to play in promoting women empowerment in developing countries, which in these days is among important targets of the sustainable development goals (SDGs).

Therefore, capacity building in these enterprises especially MSEs should be given a high priority by the policy makers in their economic development policies. Governments, 
specially at the regional level, should (i) conduct training programs routinely and in all MSME centers that focus on online marketing, entrepreneurship, management, and improvement of product quality and business efficiency; (ii) provide alternative funding facilities with low interest rates and non-burdensome requirements; (iii) provide technical assistance (e.g. production, maintenance of machines) and non-technical assistance (e.g. marketing, promotion, distribution) directly in the production site for new entrepreneurs in their first one to two years of running businesses; and (iv) to secure the availability of MSMEs most needed raw materials with stable prices are. In addition, all gender discrimination treatments that have been burdensome for women to run their own businesses must be eliminated, and all existing government initiated programs to support MSMEs must be fully socialized so that all MSMEs are fully aware of such programs/facilities.

However, this study has several limitations, especially with respect to the third and fourth research questions. Secondary data used does not have information about the main/initial motivation of MSME owners to run their own business rather than work elsewhere.

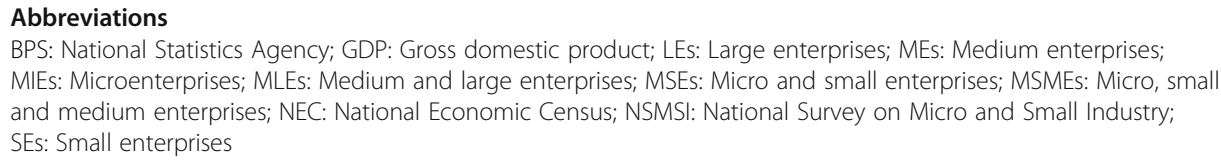

\section{Availability of data and materials}

The (secondary/national) datasets analysed during the current study are available from the following three sources. 1) Ministry of Cooperative and Small Medium Enterprise (online data):

http://www.depkop.go.id/berita-informasi/data-informasi/data-umkm/.

2) BPS (https://www.bps.go.id):

2a) 2015 National Survey on Micro and Small Industry (NSMSI)(hard copy data):

Title of the Publication: PROFIL INDUSTRI MIKRO DAN KECIL 2015 (PROFILE OF MICRO AND.

SMALL INDUSTRIES 2015).

Nomor Publication: 05320.1502

Year of publication: 2016

Web address: https://www.bps.go.id/publication/2015/12/03/24f9aa750909904e193d26aa/profil-.

industri-mikro-dan-kecil-2015-.

ISSN/ISBN: 1907-9451.

Publisher: BPS (Jakarta)

2b) 2016 National Economic Census (NEC) (hard copy data).

Title of the Publication: ANALISIS KETENAGAKERJAAN USAHA MIKRO KECIL (MICRO SMALL.

ENTERPRISE MANPOWER ANALYSIS).

No. Publication: 07320.1703.

Year of publication: 2017

Web address :https://www.bps.go.id/publication/2017/12/26/3d1e106a193f44a29983778e/.

analisis-hasil-listing-sensus-ekonomi-2016---analisis-ketenagakerjaan-usaha-mikro-

kecil.

ISSN/ISBN: 978-602-438-165-3.

Publisher: BPS (Jakarta).

2c) Title of Publication: STATISTIK INDONESIA 2016 (INDONESIAN STATISTICS 2016)(hard copy data).

No. Publication: 032201610 .

Year of publication: 2017

Web address: https://www.bps.go.id/publication/2016/06/29/7aa1e8f93b4148234a9b4bc3/statistic indonesia-2016.

ISSN/ISBN: 0126-2912.

Publisher: BPS (Jakarta) 
Competing interests

The author declare that he have no competing interests.

\section{Publisher's Note}

Springer Nature remains neutral with regard to jurisdictional claims in published maps and institutional affiliations.

Received: 28 August 2018 Accepted: 11 December 2018

Published online: 23 January 2019

\section{References}

ADB. (2002). Report and Recommendation of the President to the Boards of Directors on a Proposed Loan and Technical Assistance Grant to the Republic of Indonesia for the Small and Medium Enterprise Export Development Project. Jakarta: Asian Development Bank ADB RRP: INO 34331. November.

Akande, O. O., \& Ojukuku, R. M. (2008). The impact of entrepreneurial skills on small business performance in lagos - southwestern nigeria. World Conference. Halifax, Nova Scotia: International Council for Small Business.

Alarape, A. A. (2007). Entrepreneurship programs, operational efficiency and growth of small businesses. Journal of Enterprising Communities: People and Places in the Global Economy, 1(3), 222-239.

BI \& LPPI. (2015). Profil Bisnis Usaha Mikro, Kecil dan Menengah (UMKM) (business profile of micro, small and medium enterprises). Jakarta: Bank Indonesia.

BPS. (2015). Profil Industri Mikro dan Kecil Tahun 2015 (Profile of micro and small enterprises). Jakarta: Badan Pusat Statistik.

BPS. (2016). Statistik Indonesia 2016 (Indonesian statistics). Jakarta: Badan Pusat Statistik.

BPS. (2017). Analisis Ketenagakerjaan Usaha Mikro dan Kecil (Employment analysis of micro and small enterprises). Sensus Ekonomi 2016. Jakarta: Badan Pusat Statistik.

Das, S., \& Mohiuddin, K. M. (2015). Motivational factors and the constraints of women entrepreneurship development in Bangladesh. International Journal of Information, Business and Management, 7(3), 377-396.

Fiseha, G. G., \& Akeem, A. O. (2015). An assessment of the roles of small and medium enterprises (SMEs) in the loca economic development (LED) in South Africa. Journal of Economics, 6(3), 280-290.

Hapsari, Ira Maya. (2014). Identifikasi Berbagai Permasalahan yang Dihadapi oleh UKM dan Peninjauan Kembali Regulasi UKM Sebagai Langkah Awal Revitalisasi UKM (Identifying various problems faced by SMEs and SME regulatory review as the first step of SME revitalization). PERMANA, V(2), 43-47.

Lateh, M., Mohammad, D. H., \& Ab, M. S. (2017). Micro enterprise development and income sustainability for poverty reduction: a literature investigation. International Journal of Business and Technopreneurship, 7(1), 23-38.

Manning, C. (1998). Indonesian labour in transition: An east Asian success story. Cambridge, MA: Cambridge University Press.

Midgley, J. (2008). Microenterprise, global poverty and social development. International Social Work, 51(4), 467-479.

Narayanan, S. (2016). A study on the socio economic profile performance of micro enterprises runs by women self help groups in Madurai, Ramnad and Dindigul districts of Tamil Nadu. Journal of Accounting \& Marketing, 5(1), 1-9 Retrieved from https://www.omicsonline.org/open-access/a-study-on-the-socio-economic-profile-performance-of-microenterprisesruns-by-women-self-help-groups-in-madurai-ramnad-and-dindigu-2168-9601-1000147.php?aid=64647.

Oey, M. (1998). The impact of the financial crisis on Indonesian women: Some survival strategy. The Indonesian Quarterly, 26(2), 81-90.

Orlando, María Beatriz \& Molly, Pollack (2000). Microenterprises and Poverty. Evidence from Latin America. Washington, D.C: Inter-American Development Bank Sustainable Development Department Microenterprise Unit, February. Retrieved from https://publications.iadb.org/bitstream/handle/11319/5035/ Microenterprises\% 20and\%20 Poverty.pdf?sequence= 1 \&isAllowed=y. Accessed 2 Feb 2018

Oyelana, A. A., \& Adu, E. O. (2015). Small and medium enterprises (SMEs) as a means of creating employment and poverty reduction in Fort Beaufort, eastern Cape Province of South Africa. Journal of Social Sciences, 45(1), 8-15.

Raghuvanshi, Juhi, Rajat, Agrawal, \& P. K. Ghosh (2017). Analysis of Barriers to Women Entrepreneurship: The DEMATEL Approach. The Journal of Entrepreneurship, 26(2), 220-238. Retrived from http://journals.sagepub.com/impact-factor/joe. Accessed 2 Feb 2018

Rambe, P., \& Mosweunyane, L. (2017). A poverty-reduction oriented perspective to small business development in South Africa: A human capabilities approach. African Journal of Science, Technology, Innovation and Development, 9(3), $289-302$.

Rusdillah, E. (1987). Penelitian Wanita di Sektor Informal di Lima Kota (Research on women in informal sector in five cities). Paper presented at the National Training Workshop for User and Provider of Data and Indicators on Women Productive Activities. Ministry of Labour, Jakarta, 5-9 October.

Santos, Ajoqué \& Gihan, Moustafa (2016). Female entrepreneurship in developing countries - Barriers and Motivation Case Study: Egypt and Brazil. Master of Science Thesis. KTH Industrial Engineering and Management, Stockholm. Retrieved from http://www.diva-portal.se/smash/get/diva2:949759/ FULLTEXT01.pdf. Accessed 2 June 2018.

Shah, H., \& Punit, S. (2015). Women entrepreneurs in developing nations: Growth and replication strategies and their impact on poverty alleviation. Technology Innovation Management Review, 5(8), 34-43.

Tambunan, T. T. H. (1994). The role of small scale Industries in Rural Economic Development. In A case study in Ciomas subdistrict, Bogor District, West Java, Indonesia. Amsterdam: Thesis Publishers.

Tambunan, T. T. H. (2008). SMEs development in Indonesia: Do economic growth and government support matter. International Journal of Asia-Pacific Studies, 4(2), 111-133.

Tambunan, T. T. H. (2009a). Development of small and medium enterprises in ASEAN countries. New Delhi: Readworthy Publications, Ltd..

Tambunan, T. T. H. (2009b). SME in Asian developing countries. London: Palgrave Macmillan Publisher.

Tambunan, T. T. H. (2009c). Women entrepreneurs in Indonesia: Their main constraints and reasons. Journal of Asia Entrepreneurship and Sustainability, 5(3), 37-51.

Tambunan, T. T. H. (2010). Trade liberalization and SMEs in ASEAN. New York: Nova Science Publishers, Inc.. 
Tambunan, T. T. H. (2013). UMKM Indonesia. Rangkuman Hasil Sejumlah Penelitian (Indonesian MSMEs: Summary of a Number of Studies). Jakarta: Penerbit Universitas Trisakti.

Tambunan, Tulus T.H. (2015a), ASEAN Micro, Small and Medium Enterprises toward AEC 2015. Saarbrucken: Lambert Academic Publishing (LAP).

Tambunan, T. T. H. (2015b). Development of women entrepreneurs in Indonesia: Are they being 'pushed' or 'pulled'? Journal of Social Economics, 2(3), 131-149.

Tambunan, T. T. H. (2017). Usaha Mikro, Kecil, dan Menengah (Micro, Small and Medium Enterprise). Jakarta: Ghalia Indonesia.

Tambunan, T. T. H. (2018). MSMEs and access to financing in a developing economy: The Indonesian experience. In A. Woldie \& B. Thomas (Eds.), Financial entrepreneurship for economic growth in emerging nations IGI Global.

Thapa, Ajay (2016). Micro-enterprise Development as a Poverty Reduction Strategy in Nepal: A Multidimensional Analysis of the Factors Determining Micro-enterprise Performance. Research Note, Private Enterprise Development in Low Income Countries, Center for Economic Policy Research and UKaid. Retrieved from https://pedl.cepr.org/sites/default/files/ Research\%20Note\%20-\%20Microenterprise\%20 Development\%20as\% 20a\%20PovertyReduction\%20Strategy\%20in\%20Nepal_1.pdf. Accessed 5 Mar 2018.

Wijaya, A.A.M. (2008). Melihat Usaha Mikro Kecil dan Menengah (UMKM) Sebagai Upaya Penanggulangan (Looking at micro small and medium enterprises (MSMEs) as an effort to overcome). Retrieved from https://www.academia.edu/4971389/ Melihat_Usaha_Mikro_Kecil_Dan_Menengah_UMKM_Sebagai_Upaya_Penanggulangan_Kemiskinan_Sebuah _Pendekatan_Capability_Appro. Accessed 13 Jan 2018.

Yuhua, B. Z. (2013). SMEs in the APEC Region. APEC Policy Support Unit, Policy Brief No.8. December. Singapore: APEC Secretariat.

\section{Submit your manuscript to a SpringerOpen ${ }^{\circ}$ journal and benefit from:}

- Convenient online submission

- Rigorous peer review

- Open access: articles freely available online

High visibility within the field

- Retaining the copyright to your article

Submit your next manuscript at $\boldsymbol{\nabla}$ springeropen.com 